\title{
Inductive cum targeted yield model based Integrated fertilizer prescriptions for tomato (Solanum lycopersicum L.) under drip fertigation on an alfisol
}

\author{
A. Agila \\ Department of Soil Science \& Agricultural Chemistry, Directorate of Natural Resource \\ Management, Tamil Nadu Agricultural University, Coimbatore - 641003 (Tamil Nadu), India \\ R. Santhi* \\ Department of Soil Science \& Agricultural Chemistry, Directorate of Natural Resource \\ Management, Tamil Nadu Agricultural University, Coimbatore - 641003 (Tamil Nadu), India \\ S. Maragatham \\ Department of Soil Science \& Agricultural Chemistry, Directorate of Natural Resource \\ Management, Tamil Nadu Agricultural University, Coimbatore - 641003 (Tamil Nadu), India \\ R. Swarna priya \\ Department of Vegetable Science, Tamil Nadu Agricultural University, Coimbatore - 641003 \\ (Tamil Nadu), India \\ *Corresponding author Email: santhitnau@yahoo.co.in
}

\section{How to Cite}

Agila, A. et al. (2021). Inductive cum targeted yield model based Integrated fertilizer prescriptions for tomato (Solanum lycopersicum L.) under drip fertigation on an alfisol. Journal of Applied and Natural Science, 13(3), 1065 - 1071. https:// doi.org/10.31018/jans.v13i3.2883

\begin{abstract}
Soil test crop response (STCR) correlation studies under Integrated Plant Nutrition System were conducted in the western agroclimatic zone of Tamil Nadu during 2020-2021 to devise the fertilizer prescription equations for tomato (Solanum lycopersicum L.) under drip fertigation on an alfisol. The equations were derived by following Ramamoorthy's Inductive cum targeted yield model. The nutrient requirement of $\mathrm{N}, \mathrm{P}_{2} \mathrm{O}_{5}$ and $\mathrm{K}_{2} \mathrm{O}$ for producing one quintal of tomato fruit was found to be $0.22,0.11,0.27$ $\mathrm{kg}$ respectively. The per cent contribution of nutrients were $37.93,46.73$ and 29.53 of $\mathrm{N}_{1} \mathrm{P}_{2} \mathrm{O}_{5}$ and $\mathrm{K}_{2} \mathrm{O}$ from soil (Cs) and 47.84 , 31.12 and 74.13 of $\mathrm{N}, \mathrm{P}_{2} \mathrm{O}_{5}$ and $\mathrm{K}_{2} \mathrm{O}$ from fertilizers (Cf) respectively. Two organic sources were applied viz., FYM (Farm Yard Manure) and Biocompost and the per cent contribution of nutrients from FYM were 38.36, 13.22 and 52.17 of $\mathrm{N}, \mathrm{P}_{2} \mathrm{O}_{5}$ and $\mathrm{K}_{2} \mathrm{O}$ and from biocompost were 43.34, 10.90 and 57.00 of $\mathrm{N}, \mathrm{P}_{2} \mathrm{O}_{5}$ and $\mathrm{K}_{2} \mathrm{O}$ respectively. Fertilizer adjustment equations were formulated for STCR-NPK alone, STCR-IPNS (FYM) and STCR-IPNS (Biocompost) by applying the basic parameters such as NR, Cs, Cf, Cfym, Cbiocompost. A ready reckoner of fertilizer doses for a set of soil test values at yield targets 80 and $90 \mathrm{t} \mathrm{ha}^{-1}$ was computed. The findings also showed that the adoption of STCR-IPNS could save more fertilizers.
\end{abstract}

Keywords: Drip fertigation, Fertilizer prescription equations, Palaviduthi soil series, STCR-IPNS, Tomato

\section{INTRODUCTION}

Indiscriminate use of fertilizers poses a severe threat to the environment and soil health. Our concern in the field of agriculture is not only to hike production but also to conserve soil from the disproportionate fertilizer usage. Hence a balanced fertilization approach should be adhered to, which should ensure improved crop production and a healthy environment and soil. STCRIPNS approach is a conformable technique as it helps to improve crop production, protect the environment from excess fertilizers, and conserve energy by applying only the required amount of fertilizers by crop. This technique takes into consideration the nutrient requirement of a crop, contribution from soil, fertilizers and organics and the fertilizer prescription equations are developed. These fertilizer prescriptions play a major role in the prudent use of fertilizers by using the resources available to the farmers (Dey and Santhi, 2014).

Tomato is the second most commonly consumed vegetable in the world next to potato. The major tomato- 
producing countries are China, India, USA, Turkey, Egypt, Italy. India is the second-largest producer of tomato in the world with 20 million tonnes of production. The water requirement of field-grown tomato is 400 to $600 \mathrm{~mm}$ after transplantation. Water being the scarcest resource, it is obligatory to sustain and manage the use of water. By adopting contemporary irrigation approaches like drip irrigation the water use efficiency can be increased thereby increasing the area under cultivation. Fertilizer application by drip irrigation has been witnessed as the most efficacious nutrient supply method that defends water use and enhances the yield of vegetables by increasing the nutrient use efficiency (Sundaresh et al., 2019). In addition to high crop yield, drip fertigation ensures a healthy soil and environment by optimizing the use of water and fertilizers (Ankush et al., 2018). Soil test based fertilizer prescriptions were developed formerly for surface irrigation and conventional method of fertilizer application on Palaviduthi soil series (Coumaravel et al., 2012). But fertilizer prescriptions for tomato under drip fertigation is yet to be given which is need of the hour since most of the tomato cultivation is under drip fertigation. Hence the current study was performed on Palaviduthi soil series at Coimbatore district of Tamil Nadu to provide fertilizer prescriptions for tomato (Solanum lycopersicum L.) under drip fertigation.

\section{MATERIALS AND METHODS}

\section{Emplacement description and soil attributes}

A field trial was conducted to meliorate the fertilizer prescriptions for tomato (Hybrid Sivam) under drip fertigation on Palaviduthi soil series, Typic Rhodustalf during 2020-2021 at farmer's holding in Kuppanur village, Coimbatore district, which is located in the Western agro-climatic zone of Tamil Nadu at $10^{\circ} 95^{\prime}$ North latitude and $76^{\circ} 87^{\prime}$ East longitude at an altitude of $416 \mathrm{~m}$ above MSL. The soil of the experimental field was red, non-calcareous, sandy loam in texture, neutral in reaction $(\mathrm{pH}-7.41)$ and non-saline $\left(\mathrm{EC}-0.15 \mathrm{dSm}^{-1}\right)$. The initial soil available alkaline potassium permanganate nitrogen, olsen phosphorus, ammonium acetate potassium, organic carbon were $225 \mathrm{~kg} \mathrm{ha}^{-1}$ (Low), 39 $\mathrm{kg} \mathrm{ha}^{-1}$ (High), $285 \mathrm{~kg} \mathrm{ha}^{-1}$ (High), $2.64 \mathrm{~g} \mathrm{~kg}^{-1}$ (Low), respectively.

\section{Treatments}

The trial was set out in Randomized Block Design with fifteen treatments and three replications. The fifteen treatments comprised of $\mathrm{T}_{1}$ : STCR-NPK alone $-70 \mathrm{tha}$ ${ }^{1}, \mathrm{~T}_{2}$ : STCR-NPK alone - $80 \mathrm{t} \mathrm{ha}^{-1}, \mathrm{~T}_{3}$ : STCR-NPK alone - $90 \mathrm{t} \mathrm{ha}^{-1}, \mathrm{~T}_{4}$ : STCR-NPK + FYM @ $12.5 \mathrm{t} \mathrm{ha}^{-1}$ $70 \mathrm{t} \mathrm{ha}^{-1}, \mathrm{~T}_{5}$ : STCR-NPK + FYM @ $12.5 \mathrm{t} \mathrm{ha}^{-1}-80 \mathrm{t} \mathrm{ha}$ ${ }^{1}, \mathrm{~T}_{6}$ : STCR-NPK + FYM @ $12.5 \mathrm{t} \mathrm{ha}^{-1}-90 \mathrm{t} \mathrm{ha}^{-1}, \mathrm{~T}_{7}$ :
FYM alone $-6.25 \mathrm{t} \mathrm{ha}^{-1}, \mathrm{~T}_{8}: \mathrm{FYM}$ alone $-12.5 \mathrm{tha}^{-1}, \mathrm{~T}_{9}$ : Biocompost alone $-2.5 \mathrm{tha}^{-1}, \mathrm{~T}_{10}$ : Biocompost alone $5 \mathrm{t} \mathrm{ha}^{-1}, \mathrm{~T}_{11}$ : STCR-NPK + Biocompost @ $5 \mathrm{t} \mathrm{ha}^{-1}-70 \mathrm{t}$ ha $^{-1}, \mathrm{~T}_{12}$ : STCR-NPK + Biocompost @ $5 \mathrm{t} \mathrm{ha}^{-1}-80 \mathrm{tha}$ ${ }^{1}, \mathrm{~T}_{13}$ : STCR-NPK + Biocompost @ $5 \mathrm{t} \mathrm{ha}^{-1}-90 \mathrm{t} \mathrm{ha}^{-1}$, $\mathrm{T}_{14}$ : Blanket + FYM @ $12.5 \mathrm{t} \mathrm{ha}^{-1}, \mathrm{~T}_{15}$ : Absolute control. The fertilizer doses for STCR treatments were calculated based on existing FPEs (Fertilizer Prescription Equations) for tomato under conventional method of irrigation and fertilizer application on Palaviduthi soil series (Coumaravel et al., 2012). The nutrients were given as Urea $(46 \% \mathrm{~N})$, Single Super Phosphate (SSP, $16 \% \mathrm{P}_{2} \mathrm{O}_{5}$ ) and Muriate of Potash (MOP, $60 \% \mathrm{~K}_{2} \mathrm{O}$ ). The entire amount of SSP was given basally whereas Urea and MOP were given through drip fertigation at weekly intervals (Rajan et al., 2014). For STCR - IPNS treatments from $\mathrm{T}_{4}$ to $\mathrm{T}_{6}, \mathrm{FYM} @ 12.5 \mathrm{t} \mathrm{ha}^{-1}$ was applied as basal in addition to the calculated doses of fertilizers and treatments from $T_{11}$ to $T_{13}$, Biocompost @ $5 \mathrm{t} \mathrm{ha}^{-1}$ was applied in addition to the calculated doses of fertilizers.

\section{Soil and plant analysis}

The soil samples were collected antecedent to fertilizer and manure application and analyzed for alkaline $\mathrm{KMnO}_{4}-\mathrm{N}$ (Subbiah and Asija, 1956), Olsen-P (Olsen et al., 1954) and $\mathrm{NH}_{4} \mathrm{OAc}-\mathrm{K}$ (Stanford et al., 1949). The tomato crop (Hybrid sivam) duration was from December 2020 to April 2021. As per the Crop production guide 2020 of TNAU, all the package of practices were followed. The fruit and haulm yield were noted for different treatments and samples were collected and analyzed for total $N$ (Humphries, 1956), total $P$ and $K$ (Jackson, 1973). The total N, P and K uptake for different treatments were calculated by taking into account the dry matter yield and N, P and K content in the fruit and haulm of tomato plant. SPSS statistical software was used to expound the effect of varied treatments imposition on fruit yield and N, P and K uptake (Nie et al., 1975).

\section{Ciphering of basic parameters}

Using the data on fruit yield, nutrient uptake, initial soil available nutrients and fertilizer doses applied, the basic parameters such as Nutrient requirement (NR) in $\mathrm{kg} \mathrm{q}^{-1}$, Per cent contribution of nutrients from soil to total nutrient uptake (Cs), Per cent contribution of nutrients from fertilizer to total nutrient uptake (Cf) and Per cent contribution of nutrients from organics (FYM and Biocompost) to total uptake (Co) (Ramamoorthy et al., 1967) were estimated. These basic parameters were utilized to formulate the fertilizer prescription equations for STCR alone, STCR-IPNS (FYM) and STCR-IPNS (Biocompost) to suit tomato under drip fertigation. 
Agila, A. et al. / J. Appl. \& Nat. Sci. 13(3), 1065 - 1071 (2021)

\section{RESULTS AND DISCUSSION}

Fruit yield and nutrient uptake in assorted treatments

The fruit yield ranged from 39.6 to $99.0 \mathrm{t} \mathrm{ha}^{-1}$ due to different treatments imposition (Fig.1). The SEd and $C D(P=0.05)$ values for fruit yield were found to be 730.6 and 1499.2, respectively. Among the various treatments, the highest fruit yield of $99.0 \mathrm{t} \mathrm{ha}^{-1}$ was recorded in $\mathrm{T}_{6}$ : STCR-NPK + FYM @ $12.5 \mathrm{t} \mathrm{ha}^{-1}-90 \mathrm{t} \mathrm{ha}^{-1}$ followed by $\mathrm{T}_{13}$ : STCR-NPK + Biocompost @ $5 \mathrm{t} \mathrm{ha}^{-1}$ $90 \mathrm{t} \mathrm{ha}^{-1}$ with the yield of $94.5 \mathrm{t} \mathrm{ha}^{-1}$. There was a significant difference $(P=0.05)$ in the fruit yield recorded in $T_{6}$ and $T_{13}$. Higher fruit yield in STCR-IPNS higher yield target was in accordance with the results given by Basavaraja et al., (2019) at Bengaluru, Karnataka for eggplant. The fruit yield in $\mathrm{T}_{3}$ : STCR-NPK alone $-90 \mathrm{t}$ $\mathrm{ha}^{-1}$ was found to be $89.2 \mathrm{t} \mathrm{ha}^{-1}$, which was 9.8 and 5.3 $\mathrm{t}$ ha ${ }^{-1}$ lesser than treatments $\mathrm{T}_{6}$ and $\mathrm{T}_{13}$. This indicated the superiority of fruit yield in STCR-IPNS over STCRNPK alone. This was due to the fact that the sole application of inorganic fertilizers lacked some other necessary nutrients that would be available in organic manures. Moreover, there was synchrony in nutrient release and plant recovery resulted in better yield and improved soil properties in STCR-IPNS (Meena et al., 2019). The FYM alone treatments recorded more fruit yield of 43.5 and $45.7 \mathrm{t} \mathrm{ha}^{-1}$ at 6.25 and $12.5 \mathrm{t} \mathrm{ha}^{-1} \mathrm{FYM}$ which was greater than Biocompost alone treatments with fruit yield of 41.1 and $42.2 \mathrm{t} \mathrm{ha}^{-1}$ at 2.5 and $5 \mathrm{t} \mathrm{ha}^{-1}$ biocompost. Fruit yield was found to be minimum in Absolute control with a yield of $39.6 \mathrm{t} \mathrm{ha}^{-1}$. The higher fruit yield under drip fertigation might be due to the maximum availability of nutrients and water in the root vicinity at the right time of crop demand (Kale et al., 2018; Rongate et al., 2017).

The N, P and K uptake ranged from 83.84 to $236.79 \mathrm{~kg}$ $\mathrm{ha}^{-1}, 18.46$ to $54.61 \mathrm{~kg} \mathrm{ha}^{-1}$ and 83.27 to $260.18 \mathrm{~kg} \mathrm{ha}^{-1}$, respectively (Fig.2). The SEd and CD $(P=0.05)$ values were found to be 2.12 and 4.35 for $\mathrm{N}$ uptake, 0.31 and 0.63 for $\mathrm{P}$ uptake and 2.08 and 4.28 for $\mathrm{K}$ uptake, respectively. The $\mathrm{N}, \mathrm{P}$ and $\mathrm{K}$ uptake were also reported to be higher in $\mathrm{T}_{6}$ : STCR-NPK + FYM @ $12.5 \mathrm{t} \mathrm{ha}^{-1}$ $90 \mathrm{t} \mathrm{ha}^{-1}$ with $236.79,54.61$ and $260.18 \mathrm{~kg} \mathrm{ha}^{-1}$ followed by $\mathrm{T}_{13}$ : STCR- NPK + Biocompost @ 5 t ha ${ }^{-1}$ $90 \mathrm{t} \mathrm{ha}^{-1}$ with $231.93,51.46$ and $251.91 \mathrm{~kg} \mathrm{ha}^{-1}$ respectively. The $\mathrm{N}, \mathrm{P}$ and $\mathrm{K}$ uptake in $\mathrm{T}_{6}$ and $\mathrm{T}_{13}$ showed a significant difference $(P=0.05)$. The $N, P$ and $K$ uptake was recorded the highest in STCR-IPNS treatments which is analogous to the uptake given by Vijayakumar et al. (2017) on Lithic Haplustept at Krishnagiri, Tamil Nadu for SRI rice. Owing to the increased application rate and availability of nitrogen in the soil, the nitrogen uptake is on the higher side (Kohire and Das, 2015 for chilli). The upsurged phosphorus and potassium uptake were due to the higher cation exchange capacity of plant roots influenced by nitrogen. Since the fertilizers were frequently given via drip fertigation at lower concentrations, the nutrients were efficiently absorbed by the plant roots with inconsequential loss by leaching, which also increased the nutrient uptake (Ankush et al., 2018).

\section{Response to $\mathrm{N}, \mathrm{P}_{2} \mathrm{O}_{5}$ and $\mathrm{K}_{2} \mathrm{O}$ and percent achievement}

The response of fertilizers to fruit yield was estimated by finding the difference in fruit yield in absolute control and fruit yield in different treatments which varied from 59.4 to $1.5 \mathrm{t} \mathrm{ha}^{-1}$ (Table 1). The response was higher in $\mathrm{T}_{6}$ : STCR-NPK + FYM @ $12.5 \mathrm{t} \mathrm{ha}^{-1}$ - $90 \mathrm{t} \mathrm{ha}^{-1}$ with $59.4 \mathrm{t} \mathrm{ha}^{-1}$ succeeded by $\mathrm{T}_{13}$ : STCR-NPK + Biocompost @ $5 \mathrm{t} \mathrm{ha}^{-1}-90 \mathrm{t} \mathrm{ha}^{-1}$ with $54.9 \mathrm{t} \mathrm{ha}^{-1}$. The results were similar to the response trend given by Mohanapriya et al., (2020) on Typic Rhodustalf at Coimbatore, Tamil Nadu, for hybrid maize. The least response was observed in $\mathrm{T}_{9}$ : Biocompost alone $-2.5 \mathrm{t} \mathrm{ha}^{-1}$.

Table 1. Response of fertilizers to fruit yield and per cent achievement

\begin{tabular}{|c|c|c|c|c|c|c|c|}
\hline \multirow[t]{2}{*}{ Trt. } & \multirow{2}{*}{$\begin{array}{l}\text { Yield } \\
\left.\text { (t ha }^{-1}\right)\end{array}$} & \multirow{2}{*}{$\begin{array}{l}\text { Response } \\
\left(\mathrm{t} \mathrm{ha}^{-1}\right)\end{array}$} & \multirow{2}{*}{$\begin{array}{l}\text { Percent } \\
\text { Achievement } \\
(\%)\end{array}$} & \multirow[t]{2}{*}{ Trt. } & \multirow{2}{*}{$\begin{array}{l}\text { Yield } \\
\left(\text { t ha }^{-1}\right)\end{array}$} & \multirow{2}{*}{$\begin{array}{l}\text { Response } \\
\left(\mathrm{t} \mathrm{ha}^{-1}\right)\end{array}$} & \multirow{2}{*}{$\begin{array}{l}\text { Percent } \\
\text { Achievement } \\
(\%)\end{array}$} \\
\hline & & & & & & & \\
\hline $\mathrm{T}_{1}$ & 74.4 & 34.8 & 106 & $\mathrm{~T}_{8}$ & 45.7 & 6.1 & \\
\hline $\mathrm{T}_{2}$ & 83.2 & 43.6 & 104 & $\mathrm{~T}_{9}$ & 41.1 & 1.5 & \\
\hline $\mathrm{T}_{3}$ & 89.2 & 49.6 & 99 & $\mathrm{~T}_{10}$ & 42.2 & 2.6 & \\
\hline $\mathrm{T}_{4}$ & 82.6 & 43.0 & 118 & $\mathrm{~T}_{11}$ & 77.7 & 38.1 & 111 \\
\hline $\mathrm{T}_{5}$ & 90.4 & 50.8 & 113 & $\mathrm{~T}_{12}$ & 87.2 & 47.6 & 109 \\
\hline $\mathrm{T}_{6}$ & 99.0 & 59.4 & 110 & $\mathrm{~T}_{13}$ & 94.5 & 54.9 & 105 \\
\hline $\mathrm{T}_{7}$ & 43.5 & 3.9 & & $\mathrm{~T}_{15}$ & 39.6 & & \\
\hline
\end{tabular}

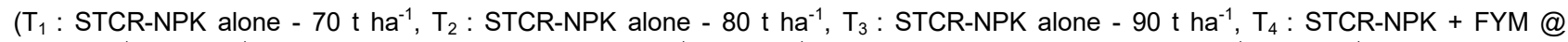

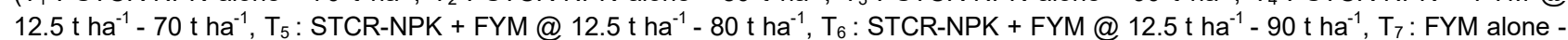
$6.25 \mathrm{tha}^{-1}, \mathrm{~T}_{8}$ : FYM alone - $12.5 \mathrm{tha}^{-1}, \mathrm{~T}_{9}$ : Biocompost alone $-2.5 \mathrm{tha}^{-1}, \mathrm{~T}_{10}$ : Biocompost alone $-5 \mathrm{t}$ ha ${ }^{-1}, \mathrm{~T}_{11}: \mathrm{STCR}-\mathrm{NPK}+$ Biocompost @ $5 \mathrm{t} \mathrm{ha}^{-1}-70 \mathrm{t} \mathrm{ha}^{-1}, \mathrm{~T}_{12}:$ STCR-NPK + Biocompost @ $5 \mathrm{t} \mathrm{ha}^{-1}-80 \mathrm{t} \mathrm{ha}{ }^{-1}, \mathrm{~T}_{13}:$ STCR-NPK + Biocompost @ $5 \mathrm{t}$ ha ${ }^{-1}-$ $90 \mathrm{t} \mathrm{ha}^{-1}, \mathrm{~T}_{15}$ : Absolute control) 
Table 2. Ready reckoner of fertilizer doses for STCR-NPK alone, STCR-IPNS (FYM) and STCR-IPNS (Biocompost) for desired yield target of $80 \mathrm{tha}^{-1}$ of tomato under drip fertigation

\begin{tabular}{|c|c|c|c|c|c|}
\hline $\begin{array}{l}\text { Soil Test } \\
\text { Values }\end{array}$ & NPK alone & $\begin{array}{l}\text { NPK+FYM @ } \\
12.5 \text { t ha }^{-1}\end{array}$ & $\begin{array}{l}\text { Reduction over } \\
\text { NPK alone }\end{array}$ & $\begin{array}{l}\text { NPK+Biocompost } \\
\text { @ } 5 \mathrm{t} \mathrm{ha}^{-1}\end{array}$ & $\begin{array}{l}\text { Reduction over } \\
\text { NPK alone }\end{array}$ \\
\hline$\left(\mathrm{kg} \mathrm{ha}^{-1}\right)$ & $\left(\mathrm{kg} \mathrm{ha}^{-1}\right)$ & $\left(\mathrm{kg} \mathrm{ha}^{-1}\right)$ & $(\%)$ & $\left(\mathrm{kg} \mathrm{ha}^{-1}\right)$ & (\%) \\
\hline \multicolumn{6}{|l|}{$\mathrm{KMnO}_{4}-\mathrm{N}$} \\
\hline 180 & 226 & 184 & 19 & 197 & 13 \\
\hline 200 & 210 & 168 & 20 & 182 & 13 \\
\hline 220 & 194 & 152 & 22 & 166 & 14 \\
\hline 240 & 178 & 136 & 24 & 150 & 16 \\
\hline 260 & 163 & 121 & 26 & 134 & 18 \\
\hline 280 & 147 & 105 & 29 & 118 & 20 \\
\hline \multicolumn{6}{|l|}{ Olsen-P } \\
\hline 18 & 218 & 192 & 12 & 203 & 7 \\
\hline 20 & 211 & 185 & 12 & 196 & 7 \\
\hline 22 & 204 & 178 & 13 & 190 & 7 \\
\hline 24 & 197 & 172 & 13 & 183 & 7 \\
\hline 26 & 191 & 165 & 14 & 176 & 8 \\
\hline 28 & 184 & 158 & 14 & 169 & 8 \\
\hline \multicolumn{6}{|c|}{$\mathrm{NH}_{4} \mathrm{OAc}-\mathrm{K}$} \\
\hline 250 & 168 & 132 & 21 & 153 & 9 \\
\hline 270 & 158 & 123 & 22 & 143 & 9 \\
\hline 290 & 149 & 113 & 24 & 133 & 11 \\
\hline 310 & 139 & 104 & 25 & 124 & 11 \\
\hline 330 & 130 & 94 & 28 & 114 & 12 \\
\hline 350 & 120 & 84 & 30 & 105 & 13 \\
\hline
\end{tabular}

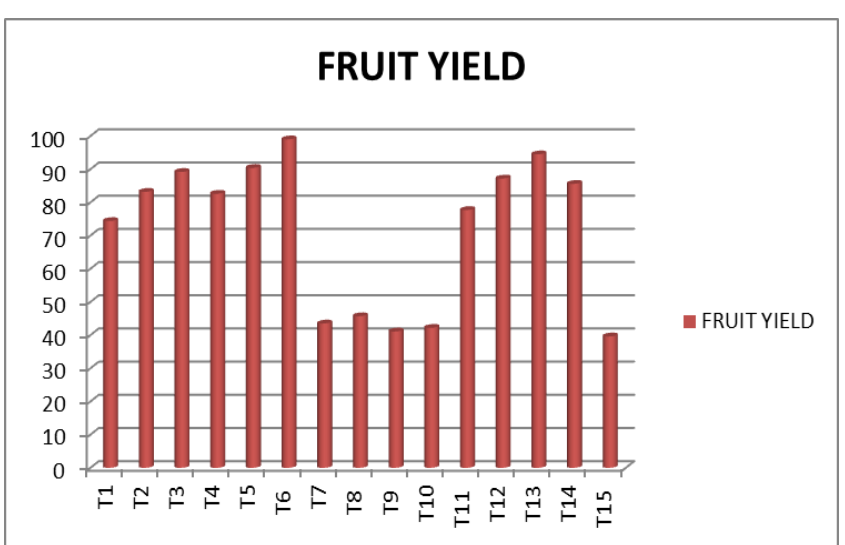

Fig.1. Fruit yield in respective treatments expressed in $t h a^{-1}$

The per cent achievement was calculated by dividing the yield obtained in the respective STCR treatments and their corresponding target yield. The per cent achievement was maximum up to $118 \%$ recorded in $\mathrm{T}_{4}:$ STCR-NPK + FYM @ $12.5 \mathrm{t} \mathrm{ha}^{-1}-70 \mathrm{t} \mathrm{ha}^{-1}$ and the minimum was ascertained to be $99 \%$ in $\mathrm{T}_{3}$ : STCRNPK alone - $90 \mathrm{t} \mathrm{ha}^{-1}$ (Table 2). Resemblant results of higher per cent achievement in STCR-IPNS (FYM) lower yield target and lower per cent achievement in STCR alone higher yield target were given by Praveena

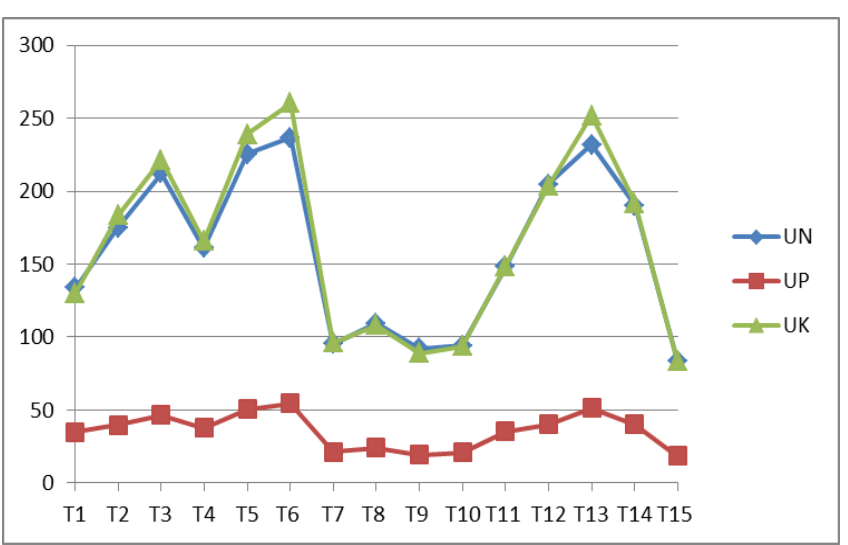

Fig. 2. Nutrient uptake in various treatments expressed in $k g h a^{-1}$

Katharine et al. (2014) on Vertic Ustropept at Coimbatore, Tamil Nadu for transgenic cotton.

\section{Basic parameters for FYM and biocompost}

Employing the data on fruit yield, NPK uptake, initial soil test values and fertilizer doses applied in the treatments $T_{1}$ to $T_{13}$ and $T_{15}$, the basic parameters such as nutrient requirement (NR), the contribution of nutrients from soil (Cs), fertilizers (Cf), FYM (Cfym) and biocompost (Cbiocompost) were worked out. They were utilized for 
Agila, A. et al. / J. Appl. \& Nat. Sci. 13(3), 1065 - 1071 (2021)

Table 3. Ready reckoner of fertilizer doses for STCR-NPK alone, STCR-IPNS (FYM) and STCR-IPNS (Biocompost) for desired yield target of $90 \mathrm{t} \mathrm{ha}^{-1}$ of tomato under drip fertigation

\begin{tabular}{|c|c|c|c|c|c|}
\hline $\begin{array}{l}\text { Soil Test } \\
\text { Values }\end{array}$ & $\begin{array}{l}\text { NPK } \\
\text { alone }\end{array}$ & $\begin{array}{l}\text { NPK+FYM @ } \\
12.5 \text { t ha }^{-1}\end{array}$ & $\begin{array}{l}\text { Reduction over } \\
\text { NPK alone }\end{array}$ & $\begin{array}{l}\text { NPK+Biocompost @5 } \\
\text { t ha }{ }^{-1}\end{array}$ & $\begin{array}{l}\text { Reduction over } \\
\text { NPK alone }\end{array}$ \\
\hline$\left(\mathrm{kg} \mathrm{ha}^{-1}\right)$ & $\left(\mathrm{kg} \mathrm{ha}^{-1}\right)$ & $\left(\mathrm{kg} \mathrm{ha}^{-1}\right)$ & $(\%)$ & $\left(\mathrm{kg} \mathrm{ha}^{-1}\right)$ & (\%) \\
\hline \multicolumn{6}{|l|}{$\mathrm{KMnO}_{4}-\mathrm{N}$} \\
\hline 180 & 272 & 230 & 15 & 243 & 11 \\
\hline 200 & 256 & 214 & 16 & 228 & 11 \\
\hline 220 & 240 & 198 & 18 & 212 & 12 \\
\hline 240 & 224 & 182 & 19 & 196 & 13 \\
\hline 26---0 & 209 & 167 & 20 & 180 & 14 \\
\hline 280 & 193 & 151 & 22 & 164 & 15 \\
\hline \multicolumn{6}{|l|}{ Olsen-P } \\
\hline 18 & 253 & 227 & 10 & 238 & 6 \\
\hline 20 & 246 & 220 & 11 & 231 & 6 \\
\hline 22 & 239 & 213 & 11 & 225 & 6 \\
\hline 24 & 232 & 207 & 11 & 218 & 6 \\
\hline 26 & 226 & 200 & 12 & 211 & 7 \\
\hline 28 & 219 & 193 & 12 & 204 & 7 \\
\hline \multicolumn{6}{|c|}{$\mathrm{NH}_{4} \mathrm{OAc}-\mathrm{K}$} \\
\hline 250 & 204 & 168 & 18 & 189 & 7 \\
\hline 270 & 194 & 159 & 18 & 179 & 8 \\
\hline 290 & 185 & 149 & 19 & 169 & 9 \\
\hline 310 & 175 & 140 & 20 & 160 & 9 \\
\hline 330 & 166 & 130 & 22 & 150 & 10 \\
\hline 350 & 156 & 120 & 23 & 141 & 10 \\
\hline
\end{tabular}

the formulation of fertilizer prescriptions under STCRNPK alone, STCR-IPNS (FYM) and STCR-IPNS (Biocompost). Examining the basic data, it can be concluded that the amount of nutrient required to produce a quintal of tomato fruit was $0.22 \mathrm{~kg} \mathrm{~N}, 0.11 \mathrm{~kg}$ $\mathrm{P}_{2} \mathrm{O}_{5}, 0.27 \mathrm{~kg} \mathrm{~K} \mathrm{O}_{2} \mathrm{O}$ (Fig.3). The $\mathrm{K}_{2} \mathrm{O}$ requirement was higher subsequently followed by $\mathrm{N}$ and $\mathrm{P}_{2} \mathrm{O}_{5}$. The nutrient requirement was in accordance with the results of Jadhav et al. (2013) on Typic Ustorthent at Rahuri, Ahmednagar for tomato. The per cent contribution of nutrients from soil to total nutrient uptake was estimated from absolute control and the values were 37.93 for $\mathrm{N}, 46.73$ for $\mathrm{P}_{2} \mathrm{O}_{5}$ and 29.53 for $\mathrm{K}_{2} \mathrm{O}$ (Fig.4). The per cent contribution of $\mathrm{P}_{2} \mathrm{O}_{5}$ from soil was higher compared to $\mathrm{N}$ and $\mathrm{K}_{2} \mathrm{O}$ which is similar to the findings of Bagavathi ammal et al. (2020) on Typic Ustropept at Karikalampakkam village, U.T. of Puducherry for bhendi; Muralidharudu et al. (2011) for tomato. The per cent contribution of nutrients from fertilizer to total nutrient uptake was estimated from NPK alone, NPK-FYM treated plots and NPK-Biocompost treated plots. The values were found to be 47.84 for $\mathrm{N}, 31.12$ for $\mathrm{P}_{2} \mathrm{O}_{5}$ and 74.13 for $\mathrm{K}_{2} \mathrm{O}$ (Fig.4). The per cent contribution of $\mathrm{K}_{2} \mathrm{O}$ from fertilizer was higher followed by $\mathrm{N}$ and $\mathrm{P}_{2} \mathrm{O}_{5}$. The higher contribution of $\mathrm{K}_{2} \mathrm{O}$ from the fertilizers was due to the priming effect of $\mathrm{K}$ in addition to the interaction effect of the higher amount of $\mathrm{N}$ and $\mathrm{P}$ fertilizers which resulted in more $\mathrm{K}$ uptake (Deshpande et al., 2016 on Vertic Haplustepts at Rahuri, Maharashtra; Ray et al., 2000 on Typic Ustochrept at Barrackpore, West Bengal) The per cent contribution of nutrients from FYM to total nutrient uptake was computed from FYM treated plots and the values were 38.36, 13.22 and 52.17 for $\mathrm{N}, \mathrm{P}_{2} \mathrm{O}_{5}$ and $\mathrm{K}_{2} \mathrm{O}$ respectively (Fig.4). The per cent contribution of nutrients from biocompost to total nutrient uptake was found to be 43.34, 10.90 and 57.00 for $\mathrm{N}, \mathrm{P}_{2} \mathrm{O}_{5}$ and $\mathrm{K}_{2} \mathrm{O}$, respectively, calculated from biocompost treated plots (Fig. 4). The organic manures followed the same trend as Beena et al. (2018) reported for vegetable cowpea on a ultisol at Thrissur, Kerala, where the nutrient contribution was in order as $\mathrm{K}_{2} \mathrm{O}>\mathrm{N}>\mathrm{P}_{2} \mathrm{O}_{5}$.

\section{Fertilizer prescriptions for tomato under drip fertigation}

To compute the fertilizer doses for desired yield target of tomato under drip fertigation based on soil test values, the basic parameters were used to establish FPEs, which are provided below: 


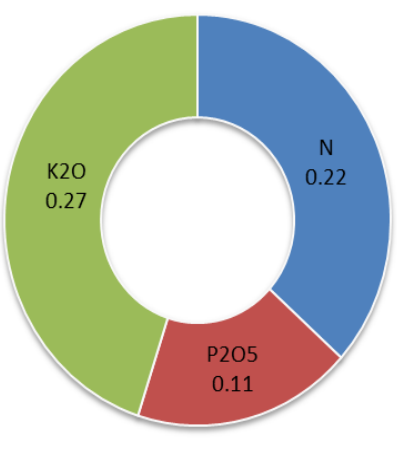

Fig. 3. Nutrient Requirement (NR) expressed in $\mathrm{kg} \mathrm{q}^{-1}$

The FPEs were utilized to develop ready reckoners for a range of soil test values at desired yield target of 80 and $90 \mathrm{t} \mathrm{ha}^{-1}$ for tomato under drip fertigation on an alfisol (Table 2,3). It is observed that at soil test values of $180: 18: 250 \mathrm{~kg} \mathrm{ha}^{-1}$ of $\mathrm{KMnO}_{4}-\mathrm{N}$, Olsen-P, $\mathrm{NH}_{4} \mathrm{OAc}-\mathrm{K}$ for yield targets 800 and $900 \mathrm{q} \mathrm{ha}^{-1}$ the calculated fertilizer doses of $\mathrm{N}, \mathrm{P}_{2} \mathrm{O}_{5}$ and $\mathrm{K}_{2} \mathrm{O}$ for NPK alone was 226, 218 and $168 \mathrm{~kg} \mathrm{ha}^{-1}$ and 272, 253 and $204 \mathrm{~kg} \mathrm{ha}^{-1}$ respectively. Under STCR-IPNS, when FYM was applied at $12.5 \mathrm{t} \mathrm{ha}^{-1}$ (Moisture content $24 \%, 0.55 \% \mathrm{~N}, 0.28 \% \mathrm{P}$ and $0.44 \% \mathrm{~K}$ ) the fertilizer savings was 42,26 and 36 $\mathrm{kg} \mathrm{N}, \mathrm{P}_{2} \mathrm{O}_{5}$ and $\mathrm{K}_{2} \mathrm{O}$. When Biocompost was applied at $5 \mathrm{t} \mathrm{ha}^{-1}$ (Moisture content $36 \%, 0.95 \% \mathrm{~N}, 0.56 \% \mathrm{P}$ and $0.50 \% \mathrm{~K}$ ) the fertilizer savings were 28,15 and $15 \mathrm{~kg}$ $\mathrm{N}, \mathrm{P}_{2} \mathrm{O}_{5}$ and $\mathrm{K}_{2} \mathrm{O}$. As the soil available $\mathrm{N}, \mathrm{P}$ and $\mathrm{K}$ increased, the percent reduction of NPK fertilizers under NPK+FYM and NPK+Biocompost increased, whereas it decreased with increasing yield targets which is in corroboration with Sivaranjani et al. (2018) on Vertic Ustropept at Coimbatore, Tamil Nadu for hybrid maize; and with Udayakumar and Santhi (2017) on Typic Ustropept at Coimbatore, Tamil Nadu for pearl millet.

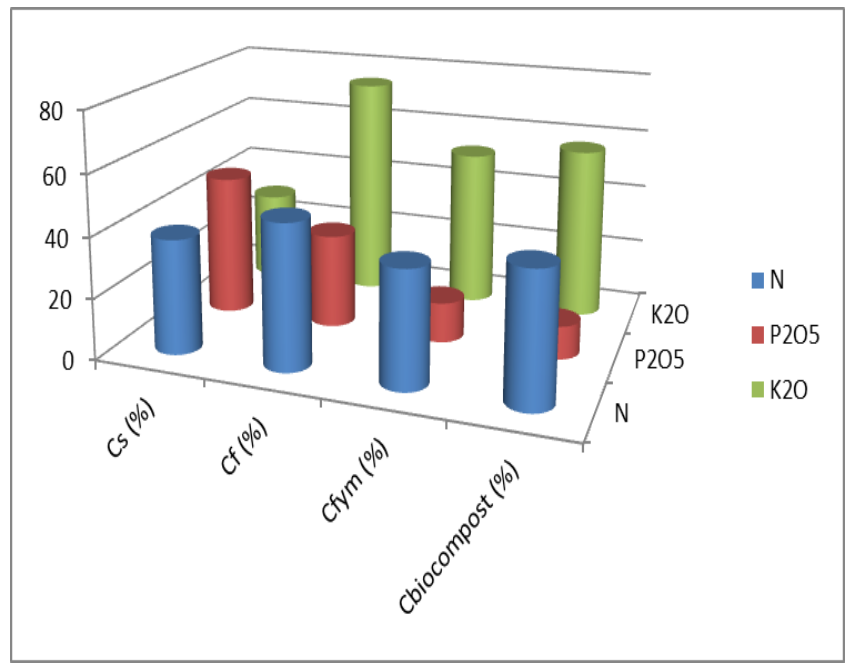

Fig. 4. Contribution of nutrients from soil (Cs), fertilizer (Cf), FYM (Cfym) and biocompost (Cbiocompost) (\%)

\section{Conclusion}

In this inquisition, the FPEs for tomato under drip fertigation on Typic Rhodustalf (red, non-calcareous, Palaviduthi soil series) has been evolved. The study concluded that by integrating STCR treatments with IPNS by application of organic manures the soil fertility, soil physical properties and microbial activities were enhanced which increased the enzyme activity in the soil which directly influenced the betterment of crop yield. Since the employment of biocompost as an organic source of fertilizer in crop cultivation has increased, the FPEs for STCR-IPNS (Biocompost) were also provided in addition to the FPEs for STCRIPNS (FYM). Hence this study provides a dual benefit to farmers where they can opt for either of the FPEs based on their resource availability.

\section{Conflict of interest}

The authors declare that they have no conflict of interest.

\section{REFERENCES}

1. Ammal, U. B., Prabhu, G. K., Coumaravel, K., Sankar, R. \& Dey, P. (2020). Integrated fertilizer prescriptions for bhendi through inductive cum targeted yield model in Bahour soil series (Typic ustropept) of Puducherry

2. Ankush, A., Singh, V., Kumar, V. \& Singh, D. P. (2018). Impact of drip irrigation and fertigation scheduling on tomato crop-An overview. Journal of Applied and Natural Science, 10(1), 165-170. https://doi.org/10.31018/jans.v 10i1.1597

3. Basavaraja, P. K., Saqeebulla, H. M., Gangamrutha, G. V., Prabhudeva, D. S. \& Dey, P. (2019). Use of STCR targeted yield approach to increasing nutrient use efficiency in eggplant (Solanum melongena L.). Journal of Pharmacognosy and Phytochemistry, 8(3), 3870-3873.

4. Beena, V. I., Dey, P., \& Raji Mol, R. P. (2018). Soil test based fertilizer recommendations under integrated plant nutrition system for vegetable cowpea [Vigna Unguiculata (L) Walp] in Ultisols of Kerala, India. Int. J. Curr. Microbiol. App. Sci, 7(1), 2420-2425. https://doi.org/10.20546/ ijcmas.2018.701.291

5. Coumaravel K. (2012). Soil Test Crop Response correlation studies through Integrated Plant Nutrition system for Maizetomato sequence. Ph.D. (Ag.), Soil science and agricultural chemistry, Tamil Nadu Agricultural University.

6. Deshpande, A. N., Dalavi, S. S., Pandey, S. H., Bhalerao, V. P. \& Gosavi, A. B. (2015). Effect of rock phosphate along with organic manures on soil properties, yield and nutrient uptake by wheat and chickpea. Journal of the Indian Society of Soil Science, 63(1), 93-99. http:// dx.doi.org/10.5958/0974-0228.2015.00013.4

7. Dey P. \& Santhi, R. (2014). Soil test based fertiliser recommendations for different investment capabilities. Soil Testing for Balanced Fertilisation - Technology, Application, Problem Solutions, P49-67.

8. Humphries, E. C. (1956). Mineral components and ash analysis. In Moderne Methoden der Pflanzenanalyse/ 
Modern Methods of Plant Analysis. Springer, Berlin, Heidelberg. 468-502.

9. Jackson M. (1973). Soil Chemical Analysis. Prentic Hall (India) Pvt. Ltd., New Delhi.

10. Jadhav, A. B., Kadlag, A. D., Deshpande, A. N., Patil, V. S. \& Durgude, A. G. (2013). Soil test crop response correlation studies for targeting yield of tomato on Entisol. Indian Journal of Horticulture, 70(1), 60-64.

11. Kale, K. D., Pawar, D. D., Hasure, R. R., Dingre, S. K. \& Bhagat, P. S. (2018). Production and Economics of Hybrid Tomato (Solanum lycopersicum) under Drip Fertigation. Agropedology, 28 (01), 1-7.

12. Kohire, V. O. P. \& Das, J. C. (2015). Effect of drip irrigation and fertilizer management on capsicum (Capsicum annum L). Journal of Agriculture and Veterinary Science, 8(1), 10-13.

13. Meena, B. P., Biswas, A. K., Singh, M., Chaudhary, R. S., Singh, A. B., Das, H. \& Patra, A. K. (2019). Long-term sustaining crop productivity and soil health in maizechickpea system through integrated nutrient management practices in Vertisols of central India. Field crops research, 232, 62-76.

14. Mohanapriya, G., Gopalakrishnan, M., Santhi, R., Maragatham, S. \& Sritharan, N. (2020). Fertilizer prescription equations for targeted yield of hybrid maize under drip fertigation on alfisol. Journal of Pharmacognosy and Phytochemistry, 9(6), 1350-1355.

15. Muralidharudu, Y. Mandal BN, Sammi Reddy K. \& A. Subba Rao. (2011). In: Progress report of the All India Coordinated Research Project for Investigation on Soil Test Crop Response Correlation, Indian Institute of Soil Science, Bhopal, 11-61.

16. Nie Norman, H., Hadlai Hull, C., Jean Jenkins, G. Karin Steinbrenner, Dale \& Bent H. (1975). SPSS: Statistical package for the social sciences: New York: McGraw-Hill.

17. Olsen, S. R. (1954). Estimation of available phosphorus in soils by extraction with sodium bicarbonate (No. 939). US Department of Agriculture.

18. Praveena Katharine, S., Santhi, R., Maragatham, S., Natesan, R., Ravikumar, V. \& Dey, P. (2013). Soil test based fertilizer prescriptions through inductive cum targeted yield model for transgenic cotton on Inceptisol. Journal of Agriculture and Veterinary Science, 6(5), 36-44.
19. Rajan, K., Haris, A. A. \& Prasad, L. K. (2014). Efficacy of conventional, solid soluble and liquid fertilizers applied through drip fertigation on tomato. Indian Journal of Horticulture, 71(2), 217-221.

20. Ramamoorthy, B., Narasimham, R. L. \& Dinesh, R. S. (1967). Fertilizer application for specific yield targets on Sonora 64 (wheat). Indian farming, 17(5), 43-45.

21. Ray, P. K., Jana, A. K., Maitra, D. N., Saha, M. N., Chaudhury, J., Saha, S., \& Saha, A. R. (2000). Fertilizer prescriptions on soil test basis for jute, rice and wheat in a Typic Ustochrept. Journal of the Indian Society of Soil Science, 48(1), 79-84.

22. Rongate, M. D., Kale, K. D., Pawar, D. D., Hasure, R. R. \& Shinde, M. G. (2017). Effect of drip fertigation on yield, water use and economics of hybrid tomato cultivated in inceptisols. Agric. for Sust. Develop, 5(1), 91-101.

23. Sivaranjani, C., Sellamuthu, K. M., Santhi, R. \& Maragatham, S. (2018). Effect of Graded Levels of Fertilizers with FYM on Yield and NPK Uptake by Hybrid Maize in Vertic ustropept. Int. J. Curr. Microbiol. App. Sci, 7(4), 3494-3498.

24. Stanford, S. \& L. English. (1949). Use of flame photometer in rapid soil tests of $\mathrm{K}$ and Ca. Agron. J., 41: 446.

25. Subbiah, B.V. and G.L. Asija. (1956). A rapid procedure for estimation of available nitrogen in soils. Curr. Sci., 25: 259-260.

26. Sundaresh, R., Basavaraja, P. K., Chikkarammappa, T., Mudalagiriyappa, M. S. H., \& Gangamrutha, G. V. (2019). Response of growth, yield attributes and yield of cabbage (Brassica oleraceae var. capitata) to different approaches of fertilizer recommendation in eastern dry zone of Karnataka, India. Journal of Pharmacognosy and Phytochemistry, 8(6), 645-649.

27. Udayakumar, S. and R. Santhi (2017). Soil test based integrated plant nutrition system for pearl millet on an Inceptisol. Research on Crops, 18(1), 21-28. http://dx.d oi.org/10.5958/2348-7542.2017.00005.5

28. Vijayakumar, M., Santhi, R. \& Jalaluddin, S. M. (2017). Refinement of fertilizer recommendation based on Soil Test Crop Response technology for rice under system of rice intensification. Journal of Applied and Natural Science, 9(2), 855 - 859. https://doi.org/10.31018/jans.v9i 2.1 286 